The Making of Rice Bran Flour-Based Sourdough Bread - Dewi, dkk Jurnal Pangan dan Agroindustri Vol.10 No.1: 28-37, Jan 2022

Accepted: 30/04/2021, Reviewed: 30/07/2021, Published: 31/01/2022

\title{
THE MAKING OF RICE BRAN FLOUR-BASED SOURDOUGH BREAD
}

\author{
Ardhia Deasy Rosita Dewi ${ }^{\star}$, Arnold Tjahjono \\ Department of Biotechnology, University of Surabaya \\ Jalan Kalirungkut Surabaya \\ *Correspondence Author, Email: deasyardhia@staff.ubaya.ac.id
}

\begin{abstract}
Sourdough is a bread made with the involvement of Lactobacillus bacteria and yeast that are naturally present in wheat flour. This study used rice bran and milk kefir grains to speed up the preparation of starters. Rice bran is used to reduce gluten content in bread as well as add nutritional value to bread. This research aims to determine the impact of the concentration of rice bran flour (0,25, and $50 \% \mathrm{w} / \mathrm{w}$ of total flour) on the physical, chemical, and organoleptic parameters of sourdough. An increase in the rice bran flour concentration leads to an increase in the $\mathrm{pH}$, hardness and brittleness of the bread. Besides, it also causes a decrease in lactic acid levels and bread expansion volume which makes the bread taste less sour. The results of the organoleptic analysis showed that sourdough with a concentration of $25 \%$ rice bran flour was the most preferred bread, as it is less sweet, without sour and bitter taste and a little bit salty. Moreover, it has a less unpleasant aftertaste, non-sour aroma, brown colour and it is not too soft in texture.
\end{abstract}

Keywords: Milk Kefir Seeds, Sourdough, Rice Bran Flour.

\section{INTRODUCTION}

Sourdough bread made with wild yeast and lactic acid bacteria. Bread that is made with this method has a slightly sour taste and a softer texture than other types of bread. sourdough-bread is made with the longest fermentation process than other yeasted-bread. This technique is the oldest bread-making technique that was firstly discovered by the ancient Egyptians around 3150 BC (Batt and Tortorello, 2014). The sourdough method can improve the quality of bread compared to other types of bread that only use yeast due to the presence of lactic acid bacteria such as Lactobacillus sp. As a consequence, lactic acid gives this bread a unique taste, a more chewy and soft texture, and increases the shelf-life of the bread (Wing \& Scott, 1999).

Compared to the technique with baker's yeast, the sourdough approach takes an extended fermentation technique due to the fact the natural microorganisms in sourdough bread aren't as active as industrial baker's yeast. This permits a degradation procedure of proteins and carbohydrates contained in flour in order that bread made with this method is easier to digest than other bread (Östman, 2003). throughout sourdough fermentation, acidification, proteolysis and enzymes activation happens. these approaches cause biochemical changes which undoubtedly have an effect on dough and baked accurate matrix and as a consequence, enhance the dietary and useful excellent of baked items (Gobbetti et al., 2014; Poutanen et al., 2009).

In this study, sourdough bread become made from a mixture of wheat flour and rice bran flour. Rice bran flour is used because it could add dietary content to sourdough bread, including vitamin B complicated, minerals, and nutrition $E$ which aren't found in wheat flour (Luh, 1991).

Lactic acid bacteria (LAB) and yeasts have been correctly used for bran fermentation (Coda et al., 2015). Rice bran fermented with yeast has been reported to include significantly higher protein content compared to non-fermented rice bran and provides an advantage when 
baking bread (K. Katina et al., 2006; Kati Katina et al., 2012; Poutanen et al., 2009; Chinma et al., 2015))

This bread also uses milk kefir grains to speed up the making of sourdough. Using of kefir grains can improve palatabilitas, decreasing spoilage, and producing flavour via corsortium of microbiology on kefir grain (Gautam, 2015). besides, Many microorganisms have been isolated from kefir microflora, sharing symbiotic relationships, inclusive of yeasts (Kluyveromyces, Candida, Torulopsis and Saccharomyces sp), lactobacilli (L. brevis, L. acidophilus, L. casei, L. helveticus, L. delbruecki), streptococci (Streptococcus salivarius), lactococci (Lc.Lactis ssp. thermophilus, Leuconostoc mesenteroides and L. cremoris) and once in a while acetic acid bacteria (de Oliveira Leite et al., 2013; Simova et al., 2002). This study was to determine the physicochemical properties of rice bran flour sourdough and the sensory preference of sourdough bread using hedonic scale.

\section{METHODS}

\section{Materials}

Wheat flour with high protein content (Cakra Kembar), distilled water, salt, rice bran flour (Gasol), milk kefir grains (Universitas Brawijaya), $\mathrm{NaOH}$ (Merck) and phenolphthalein indicator (Merck) for testing total titratable acid (TTA), TCA (Trichloroacetic acid) 15\%, concentrated $\mathrm{H}_{2} \mathrm{SO}_{4}$ (Merck), $\mathrm{CuSO}_{4}$ (Merck), and phenol 5\% (Merck).

\section{Tools}

The tools used in this research were electrical oven (Kirin), texture analyser (Agrosta), knife set, analytical balance (OHAUS), color reader (Konica Minolta), $a_{w}$ meter (Rotronic), bowl, stirrer, spectrophotometer (Genesys 105 UV-Vis), stove, centrifuge (80 - 2), and centrifuge tube.

\section{Research Design}

This study used a completely randomized design (CRD). The variables in this study were the ratio of wheat flour and rice bran flour $(0 \%, 25 \%, 50 \%$ weight/weight of flour).- The parameters measured in the dough were Total Titratable Acid (TTA), Lactic Acid, Total Sugar (TS), and $\mathrm{pH}$. Parameters measured in bread were TTA, Lactic Acid Level, $\mathrm{pH}$, texture profile (hardness, brittleness and springiness), color, water activity, specific expansion volume, and hedonic organoleptic test and structured descriptive scale.

\section{Research Stages}

\section{Dry Ingredients Preparation}

Flour is made by mixing wheat flour and rice bran flour that has been baked and sifted with a ratio of $25 \%(\mathrm{w} / \mathrm{w})$ of total flour and $50 \%(\mathrm{w} / \mathrm{w})$ of total flour

\section{Making Mother Sourdough}

Mother dough was made by mixing flour and water in a ratio of $1: 1$ and the initial culture, namely milk kefir grains as much as $20 \%$ of the total weight, which was then allowed to ferment at $37^{\circ} \mathrm{C}$. The mixture was then added with water and additional flour every day at the same ratio and discarded half from the mother sourdough until a stable culture is formed. This is characterized by a frothy mixture that is formed for approximately 6 days.

\section{Making Sourdough Starter}

Sourdough starter is made by mixing flour, water, and mother sourdough in a ratio of $2: 2: 1$. It is then fermented for 24 hours before it can be used.

\section{Making sourdough bread}

Sourdough bread is made by mixing starter with flour, salt, and water with a ratio of starter, flour, and water is 3:20:14 which is then kneaded until smooth. The dough is then 
proofed for 4 hours at a temperature of $25^{\circ} \mathrm{C}$ with a stretch and fold process every 1 hour. After the proofing process, the dough is transferred to a baking sheet and allowed to rest for 30 minutes before being baked in an oven at $230^{\circ} \mathrm{C}$ for 20 minutes.

\section{Method}

Data analysis was carried out by observing the physical properties of bread such as moisture content, specific expansion volume, color, texture profile, and water activity. Chemical tests such as TAT, PHF, TS, and pH tests were also carried out. Then, hedonic and descriptive tests were also performed to observe the color, taste, aroma, and texture of the product. The data is then processed with Minitab 18 software. There are 2 types of data, parametric data and non-parametric data obtained from this process. The parametric data were processed using the one-way ANOVA method. A further test was carried out using the Tukey method of multiple comparison analysis only if the statistical results showed a significant difference, indicated by $\mathrm{P}$-value $<0.05$. Non-parametric data were processed by the Kruskal - Wallis method. Determination of the best results was done by using the Effectiveness Index method.

\section{Analysis Procedure}

\section{Total titratable acid}

A total titratable acid (TTA) was conducted by dissolving the sample with distilled water. The solution was then diluted 10 times. $10 \mathrm{ml}$ of the liquid was then added with phenolphthalein indicator and titrated with $0.06 \mathrm{~N} \mathrm{NaOH}$ until the color changed to pink (Gül et al., 2005)

\section{Lactic Acid Test with p-Hydroxydiphenyl Reagent (PHF)}

Lactic Acid Test with p-Hydroxydiphenyl Reagent (PHF) was executed by dissolving the pre-ferment with distilled water. The solution was then added with $15 \%$ TCA with a volume ratio of $1: 1$ and allowed to rest for 10 minutes at $60^{\circ} \mathrm{C}$ and followed by a high-speed centrifugation process for 1 minute. $1 \mathrm{ml}$ of the solution was then added with $6 \mathrm{ml}$ of concentrated $\mathrm{H}_{2} \mathrm{SO}_{4}$ and shaken evenly. The solution was heated in boiling water for 10 minutes and then cooled. After cooling, the solution was added with $100 \mathrm{I}$ of $\mathrm{CuSO}_{4}$ and $200 \mathrm{I}$ of PHF and left at room temperature for 30 minutes. The solution was then observed for its absorbance on a spectrophotometer with a wavelength of $570 \mathrm{~nm}$.

\section{Total Sugar Test with Phenol Acid Reagent}

The TS test was carried out by mixing the sample with $5 \%$ phenol and concentrated $\mathrm{H}_{2} \mathrm{SO}_{4}$ in a ratio of $1: 1: 5$ and shaking evenly for each addition of ingredients. After the reagents were mixed, the mixture was left for 10 minutes at room temperature and then incubated in a water bath at $25-30^{\circ} \mathrm{C}$ for 10 minutes. The incubated solution was then observed for its absorbance on a spectrophotometer with a wavelength of $488 \mathrm{~nm}$.

\section{Texture Profile Test}

Sourdough breads that have been baked and cooled for 30 minutes are entered into a texture analyser connected to a computer which will then obtain a deformity curve (Figure 2.5). The results of the curve can show the value of hardness (crumb firmness), brittleness, and springiness of bread.

\section{Colour Profiles Test}

Sourdough bread Crust were tested with a colour reader (Konica Minolta CR300) which then obtained bread colour data in the form of $\mathrm{L}^{*}, \mathrm{a}^{*}$, and $\mathrm{b}^{*}$ data which were processed into Hue and Chroma degree data. 


\section{Water Activity Test}

The bread sample was put into a small dish which was then inserted into the $a_{w}$ meter. The tool will generate the sample $a_{w}$ value after a few minutes.

\section{Specific Development Volume Test}

The specific volume test using Charoenthaikij et al., (2012) method with measuring the sample volume before and after baking. The volume is obtained by multiplying the length, width, and height of the bread.

\section{Organoleptic Test}

Hedonic organoleptic and descriptive structured tests were conducted on 26 semitrained panellists (panellists ever consume sourdough bread) to assess their likes or dislikes of sourdough bread in terms of colour, aroma, taste, and texture. The descriptive organoleptic test was carried out by marking on a criterion scale from "very dislike" to "very much like" for the hedonic organoleptic test and describing the selected sample according to the specified criteria for the structured scale descriptive organoleptic test which was carried out by assessing the product without comparison and specifically stated the preference of the panellists on the predetermined parameters, then statistical analysis was carried out using the Minitab 18 application from the results of the organoleptic test above.

\section{RESULTS AND DISCUSSION}

\section{Chemical Characteristics Dough}

Changes in fermentation parameters when making bread are presented in Table 1. Observations were made to observe changes in the sourdough dough before fermentation (before proofing) until after fermentation (after proofing) indicated by $\mathrm{T}$ (delta change).

Table 1. Chemical characteristic of dough

\begin{tabular}{|c|c|c|c|c|}
\hline Parameter & $\begin{array}{l}\text { Concentration } \\
\text { of Rice Bran } \\
\text { Flour }(\% w / w)\end{array}$ & $\begin{array}{l}\text { Before } \\
\text { Fermentation } \\
\left(T_{0}\right)\end{array}$ & $\begin{array}{l}\text { After } \\
\text { Fermentation } \\
\text { (Ta) }\end{array}$ & $\Delta \mathrm{T}$ \\
\hline Total $\quad$ Sugar & 0 & $3818.35 \pm 63.7$ & $2315.02 \pm 14.2$ & $1503.33^{\mathrm{a}} \pm 76.9$ \\
\hline \multirow{2}{*}{$(\mathrm{g} / 100 \mathrm{~g})$} & 25 & $2991.12 \pm 51.5$ & $1916.30 \pm 29.3$ & $1074.82^{b} \pm 62.5$ \\
\hline & 50 & $1641.64 \pm 31.1$ & $1272.71 \pm 22.3$ & $368.93^{c} \pm 18.1$ \\
\hline Total Titrated & 0 & $0.014 \pm 0.001$ & $0.0315 \pm 0.0015$ & $0.0175 \pm 0.00173$ \\
\hline \multirow{2}{*}{ Acid } & 25 & $0.014 \pm 0.001$ & $0.0295 \pm 0.0008$ & $0.0155 \pm 0.000866$ \\
\hline & 50 & $0.0135 \pm 0.000$ & $0.028 \pm 0.0008$ & $0.0145 \pm 0.000866$ \\
\hline Lactic $\quad$ Acid & 0 & $1208.93 \pm 12.8$ & $1959.74 \pm 7.77$ & $750.81^{a} \pm 5.93$ \\
\hline \multirow{2}{*}{$(\mathrm{mmol} / \mathrm{L})$} & 25 & $1149.82 \pm 7.13$ & $1841.94 \pm 2.59$ & $692.12^{b} \pm 4.90$ \\
\hline & 50 & $1139.89 \pm 1.98$ & $1809.15 \pm 7.13$ & $669.26^{c} \pm 5.18$ \\
\hline \multirow[t]{3}{*}{$\mathrm{pH}$} & 0 & $5.31 \pm 0.03$ & $5.14 \pm 0.02$ & $0.17 \pm 0.017$ \\
\hline & 25 & $5.56 \pm 0.025$ & $5.42 \pm 0.03$ & $0.14 \pm 0.005$ \\
\hline & 50 & $5.57 \pm 0.025$ & $5.41 \pm 0.055$ & $0.16 \pm 0.036$ \\
\hline
\end{tabular}

The concentration of rice bran flour affected the total sugar content of the sourdough. The addition of rice bran reduces the total sugar content in the sourdough. The sugar content in the dough decreases when the bran concentration is increased. This is because the bran contains less carbohydrates. The high sugar content in the dough allows the high activity of yeast and lactic acid bacteria because sugar is a substrate for the growth of microorganisms. This can be seen in Table 1 which shows that changes in the total sugar content in the dough are lower when the rice bran concentration is increased.

The statistical test on the TAT results explained the addition of bran flour did not have a significant result on the total acid in the sourdough dough. In Table 1, it can be seen that the 
addition of rice bran flour to the dough reduces the acid content of the dough after it is fermented. Acid levels decrease due to the declining activity of microorganisms as a result of the reduced amount of substrate. Therefore, it produces less acid. The results that are not significantly different can be caused by the titration method which is not as sensitive as the spectrophotometric method so that the results obtained are similar. The titration method is considered less sensitive because the determination of colour change is a subjective process as it uses the human eye.

The results of statistical tests on the results of the lactic acid level test explained that the addition of rice bran flour had a significant effect on lactic acid levels in the sourdough dough. It can be seen in Table 1 that the giving of bran flour reduces changes in lactic acid levels in the dough. Lactic acid levels decreased when the addition of rice bran flour containing fewer substrates that supported the growth of microorganisms compared to wheat flour (Luh, 1991). The reduced substrate available for microorganism's results in reduced activity of microorganisms and leads to a decrease in lactic acid levels (Sayuti et al., 2013).

The value of statistical analysis on the $\mathrm{pH}$ test explained that the addition of rice bran flour had no significant effect on changes in the $\mathrm{pH}$ of the dough. Table 1 shows that the dough with a higher concentration of bran has a higher $\mathrm{pH}$. This happens because the lack of substrate in the bran results in a reduces in the activity of microorganisms. Therefore, the acid produced is reduced. The $\mathrm{pH}$ value is inversely proportional to the total acid and lactic acid levels. The acid produced by the activity of microorganisms is measured by the $\mathrm{pH}$ meter electrode so that the more acid produced, the lower the $\mathrm{pH}$ (Surono, 2004).

\section{Chemical Characteristics of Sourdough Bread}

The chemical characteristics and volume expansion of sourdough bread are shown in Table 2 and Table 3.

Table 2. Sourdough bread chemistry test results

\begin{tabular}{lcl}
\hline Parameter & Concentration of Rice Bran Flour $(\% \mathrm{w} / \mathrm{w})$ & Results \\
\hline Total Titrated Acid & 0 & $0.03 \pm 0.00$ \\
& 25 & $0.03 \pm 0.00$ \\
& 50 & $0.03 \pm 0.00$ \\
\hline Lactic Acid (mmol/L) & 0 & $2164.70^{\mathrm{a}} \pm 17.9$ \\
& 25 & $1977.00^{\mathrm{b}} \pm 9.72$ \\
$\mathrm{pH}$ & 50 & $1956.29^{\mathrm{b}} \pm 7.13$ \\
& 0 & $5.09^{\mathrm{a}} \pm 0.02$ \\
& 25 & $5.33^{\mathrm{b}} \pm 0.02$ \\
Water Activity & 50 & $5.43^{\mathrm{c}} \pm 0.05$ \\
& 0 & $0.89 \pm 0.05$ \\
& 25 & $0.87 \pm 0.03$ \\
& 50 & $0.90 \pm 0.03$ \\
\hline
\end{tabular}

Table 3. Sourdough bread volume test results

\begin{tabular}{lcl}
\hline Parameter & Concentration of Rice Bran Flour $(\% \mathrm{w} / \mathrm{w})$ & Results \\
\hline Specific Volume $\left(\mathrm{cm}^{3} / \mathrm{g}\right)$ & 0 & $51.443^{\mathrm{a}} \pm 3.64$ \\
& 25 & $50,773^{\mathrm{a}} \pm 2.20$ \\
& 50 & $46,667^{\mathrm{b}} \pm 1.6$ \\
\hline
\end{tabular}

Based on the results of statistical tests on TAT, it was found that the addition of bran flour did not have a significant effect on the total acid in sourdough bread. In Table 2 it can be seen that the addition of rice bran flour to the dough reduces the acid content of the bread. The total acidity did not change while the lactic acid significantly changed due to total acidity express many organic acid compounds like acetic acid and lactic acid (Hansen \& Hansen, 
1996). Then acid levels decrease due to the declining activity of microorganisms as a result of the reduced amount of substrate. Therefore, it produces less acid. The amount of acid produced will also affect the $\mathrm{pH}$ value. This can be seen in the graph where the total acid in bread containing $0 \%$ bran has a higher acid content than bread containing $25 \%$ and $50 \%$ bran.

The results of statistical tests on the results of the lactic acid level test showed that the addition of rice bran flour had a significant effect on lactic acid levels in the sourdough dough. It can be seen in Table 2 that the addition of bran flour reduces changes in lactic acid levels in the dough. Lactic acid levels decreased when the addition of rice bran flour containing fewer substrates that supported the growth of microorganisms compared to wheat flour. The reduced substrate available for microorganisms results in reduced activity of microorganisms and leads to a decrease in lactic acid levels (Sayuti et al., 2013). This finding was the similar with Gurbuz et al., (2010), that Lactic acid bacteria slower in producing lactic acid in mix cultures than specific culture.

The results of statistical tests on the results of the $\mathrm{pH}$ test showed that the addition of rice bran flour had no significant effect on changes in the $\mathrm{pH}$ of the dough. Table 1 shows that the dough with a higher concentration of bran has a higher $\mathrm{pH}$. This happens because the lack of substrate in the bran results in a decrease in the activity of microorganisms and, reported that $L A B$ grows and produce acetic acids and lactic acid slowly in a mixed culture of LAB and yeast. Acetic acid has an antimicrobial effect on rope-producing Bacillus and antimould effect on sourdough bread. Therefore, the acid produced is reduced. The $\mathrm{pH}$ value is inversely proportional to the total acid and lactic acid levels. The acid produced by the activity of microorganisms is measured by the $\mathrm{pH}$ meter electrode so that the more acid produced, the lower the $\mathrm{pH}$ (Surono, 2004).

The results of statistical tests on the results of the water activity test showed that the addition of bran flour did not have a significant effect on the water activity of sourdough bread. Table 2 shows that the $a_{w}$ value in bread increased with the addition of rice bran. This is because rice bran has hygroscopic properties so it easily absorbs water. Rice bran is hygroscopic because it has a high fiber content. The decrease in water content can also be caused by an increase in the vapor pressure in the material compared to the vapor pressure outside the material, resulting in the transfer of steam from the material to the air (Fang et al., 2007). The addition of bran flour has a significant effect on the volume of development of sourdough bread. Table 2 shows that the higher the concentration of rice bran, the lower the volume of development. This happens because the bran has a lower sugar content than wheat flour so that the bran has a lower substrate for microorganisms to use for the fermentation process. This causes the activity of yeast to decrease so that less $\mathrm{CO}_{2}$ gas which plays an important role in dough development is produced. In addition, the low gluten content in rice bran also affects the development because gluten plays a role in capturing $\mathrm{CO}_{2}$ gas produced by yeast so that bread can expand (Shewry et al., 2002).

\section{Physical and Organoleptic Characteristics of Sourdough Bread}

The characteristic color profile of sourdough bread is presented in Table 4 and then the texture profile is shown in Table 5.

Table 4. Sourdough bread color of bread crust profile test results

\begin{tabular}{|c|c|c|c|c|c|c|c|}
\hline $\begin{array}{l}\text { Concentration } \\
\text { Rice Bran } \\
(\% \mathrm{w} / \mathrm{w})\end{array}$ & $\begin{array}{r}\text { of } \\
\text { Flour }\end{array}$ & $\mathbf{L}^{*}$ & $A^{*}$ & $\mathrm{~B}^{*}$ & 'Hue & Chroma & Color \\
\hline 0 & & $\begin{array}{l}125,69 \\
\pm 8.56 \\
\end{array}$ & $\begin{array}{l}14,59 \pm \\
4.40\end{array}$ & $\begin{array}{l}21,61 \\
\pm 7.03 \\
\end{array}$ & $\begin{array}{l}34,022 \\
\pm 2.52 \\
\end{array}$ & $26.07^{a b} \pm 10.09$ & Red \\
\hline 25 & & $\begin{array}{l}120,83 \pm \\
2.89\end{array}$ & $\begin{array}{l}15,65 \\
\pm 3.54 \\
\end{array}$ & $\begin{array}{l}36,24 \pm \\
7.27\end{array}$ & $\begin{array}{l}23,362 \\
\pm 11.1\end{array}$ & $39,48^{a} \pm 6.49$ & Red \\
\hline 50 & & $\begin{array}{l}113.26 \\
\pm 5.57 \\
\end{array}$ & $\begin{array}{r}10,54 \\
\pm 1.15 \\
\end{array}$ & $\begin{array}{l}14,96 \pm \\
2.04\end{array}$ & $\begin{array}{l}14,967 \\
\pm 5.42 \\
\end{array}$ & $18,31^{b} \pm 2.28$ & $\begin{array}{l}\text { Red } \\
\text { Purple }\end{array}$ \\
\hline
\end{tabular}


The results of statistical tests on the color profile showed that the addition of rice bran flour did not have a significant effect on the hue degree and $L^{*}$ value but had a significant effect on the chroma degree. The degree of brightness indicated by the $L^{*}$ value and the color of the bread indicated by the degree of hue was not significantly different due to the Maillard reaction in the baking process which caused the color to become darker. Color changes occur during the Maillard reaction where the original color of the material will first change to a golden color, then reddish-brown and over time it will become dark brown.The degree of chroma which showed a significant difference in color intensity was caused by the addition of rice bran flour where the degree of chroma formed a parabola. This is because the color of the bran itself is light brown, so the addition of the bran will clarify the brown color of the bread, but if too much is added, the overall color of the bread will turn dark brown so that the intensity of the color decreases. Sourdough bread with addition of wheat bran had $\left(a^{*}\right)$ value means that more red in color. Carotenoid pigments from wheat bran could be responsible for the redness of the wheat bran bread crumb and crust (Torkamani et al., 2015).

Table 5. Sourdough bread texture profile

\begin{tabular}{|c|c|c|c|}
\hline $\begin{array}{l}\text { Concentration of Rice Bran } \\
\text { Flour }(\% w / w)\end{array}$ & Hardness (g) & Brittleness (g) & Springiness (g) \\
\hline 0 & $1085.33^{b} \pm 8.33$ & $989^{b} \pm 5.29$ & $0.86 \pm 0.025$ \\
\hline 25 & $1097.66^{\mathrm{ab}} \pm 6.11$ & $1003.33^{\mathrm{a}} \pm 1.53$ & $0.86 \pm 0.065$ \\
\hline 50 & $1104.66 a \pm 6.66$ & $1008^{a} \pm 1.00$ & $0.87 \pm 0.029$ \\
\hline
\end{tabular}

The results of statistical tests on the results of the texture analyzer development test showed that the addition of bran flour had a significant effect on the hardness and brittleness of bread. However, it did not significantly affect the springiness of the bread. Table 4 shows that when the concentration of bran flour is increased, the hardness and brittleness of sourdough increase. The hardness of bread can be affected by the ingredients added to the dough, in this case, bran flour and baking conditions. Rice bran flour contains a lot of fiber(Luh, 1991) so that it makes the bread produced harder so that the more bran flour is added, the harder the bread is produced (Chang et al., 2016). Brittleness in food can be affected by hardness. This is because hard materials tend to break easily (Rösler et al., 2007).

Based on the results of nonparametric statistical tests using the Kruskal - Wallis method, there were significant differences between variations in the concentration of bran flour on aspects of texture, taste, and aftertaste $(P$-value $<0.05)$ and there was no significant difference between variations in the concentration of bran flour on aspects of color and aroma (Pvalue $>0.05$ ). The results of the hedonic test in table 6 show that the highest total score was achieved by sourdough with $25 \%$ substitution of bran flour which was then followed by a descriptive test whose results can be seen in Table 7.

Table 6. Sourdough bread organoleptic test results

\begin{tabular}{lllllll}
\hline & \multicolumn{5}{c}{ Mean Score } & Total \\
\cline { 2 - 6 } & Color & Texture & Taste & Aroma & Aftertaste & score \\
\hline $\mathbf{0 \%}$ bran & $3.69 \pm 0.77$ & $3.31 \pm 0.77$ & $3.92 \pm 0.87$ & $3.42 \pm 0.92$ & $3.46 \pm 1.12$ & 17.81 \\
$\mathbf{2 5 \%}$ bran & $4.11 \pm 0.69$ & $3.96 \pm 0.854$ & $4.54 \pm 0.57$ & $3.65 \pm 0.998$ & $3.76 \pm 1.01$ & 20.04 \\
& & & & & & \\
$\mathbf{5 0 \%}$ bran & $3.73 \pm 0.98$ & $3.19 \pm 1.03$ & $3.26 \pm 0.94$ & $3.61 \pm 0.73$ & $2.96 \pm 0.98$ & 16.73 \\
\hline
\end{tabular}


Table 7. Descriptive test results sourdough bread structured scale

\begin{tabular}{ll}
\hline Structured Scale Descriptive Organoleptic Test Parameters & Intensity \\
\hline Sweetness & Not sweet enough \\
Sour taste & Not Sour \\
Texture (Tenderness) & Less Soft \\
Aftertaste (Language) & Less Harmful \\
Salty taste & Salty \\
Bitter taste & Not Bitter \\
Sour Aroma & Not Sour \\
Brown) & Brown \\
\hline
\end{tabular}

Table 8. The results of the best treatment of sourdough bread

\begin{tabular}{|c|c|c|c|c|c|}
\hline $\begin{array}{l}\text { Concentration of } \\
\text { Bran Flour }(\% \mathrm{w} / \mathrm{w})\end{array}$ & Rice & $\begin{array}{l}\text { Chemical } \\
\text { Parameters }\end{array}$ & $\begin{array}{l}\text { Organoleptic } \\
\text { Parameters }\end{array}$ & Total & Rank \\
\hline 0 & & 0.3 & 0.16 & 0.46 & 2 \\
\hline 25 & & 0.02 & 0.7 & 0.71 & 1 \\
\hline 50 & & 0 & 0.14 & 0.14 & 3 \\
\hline
\end{tabular}

The effectiveness index method was used to determine the best treatment and is shown in Table 8. The parameters used are chemical parameters with a variable weight of 0.3 and organoleptic parameters with a variable weight of 0.7 . The weight of the given variable is determined based on the importance of each parameter by the researcher. The weight of the organoleptic parameter variables is higher because the organoleptic parameters are directly related to the level of people's preference for the product and the level of product acceptance because people are more concerned with the taste, colour, aroma, texture, and aftertaste of the product than the chemical content of the product.

The chemical parameters considered are total titrated acid and lactic acid levels with values of 0.15 and 0.15 , respectively. Organoleptic parameters that are taken into account are taste, aroma, colour, texture, and aftertaste with each value of $0.15 ; 0.15 ; 0.15 ; 0.15$; and 0.1 . The aftertaste parameter is given a lower value because this parameter is considered less important by the community.

Based on the results of determining the best results using the effectiveness index method, it was concluded that sourdough with $25 \%$ bran content had the highest rank and sourdough with $50 \%$ bran content had the lowest rank. From the chemical parameters, sourdough with $0 \%$ bran content had the highest value with a value of 0.3 and from organoleptic parameters sourdough with $25 \%$ bran content had the highest value with a value of 0.7 . Sourdough with $25 \%$ rice bran obtained the highest rank because it obtained the highest total value of chemical parameters and organoleptic parameters which were added up with a total value of 0.714906 .

\section{CONCLUSION}

Variations in the concentration of bran flour affect the total sugar content of the dough, lactic acid content of dough and bread, bread $\mathrm{pH}$ value, bread expansion volume, chroma degree value, hardness value, and bread brittleness value. The concentration of bran flour has no effect on the total acid value of dough and bread, dough $\mathrm{pH}$ value, $\mathrm{a}_{w}$ value, hue degree value, $L^{*}$ value, and bread springiness. The results of the organoleptic test showed that sourdough with a concentration of $25 \%$ bran flour was the most preferred sourdough by the panellists; the description of this bread is it has a less sweet taste, without sour taste, salty taste, without a bitter taste, without sour taste, has a less unpleasant aftertaste, less soft texture, and brown colour and the results of the effectiveness index test showed that 
The Making of Rice Bran Flour-Based Sourdough Bread - Dewi, dkk Jurnal Pangan dan Agroindustri Vol.10 No.1: 28-37, Jan 2022

sourdough with $25 \%$ bran flour concentration was the best treatment based on the total value of chemical and organoleptic parameters.

\section{REFERENCES}

Batt, C, A., \&Tortorello, M, L. (2014). Encyclopedia of Food Microbiology (2nd Edition). Academic Press.

Chang, R.-C., Li, C.-Y., \& Shiau, S.-Y. (2016). Physico-chemical and sensory properties of bread enriched with lemon pomace fiber. Czech Journal of Food Sciences, 33(No. 2), 180-185. https://doi.org/10.17221/496/2014-CJFS

Charoenthaikij, P., Jangchud, K., Jangchud, A., Prinyawiwatkul, W. and No, H.K. (2012). Composite wheat-germinated brown rice flour: selected physicochemical properties and bread application. International Journal of Food Science and Technology, 47(1), 75-82. https:// doi.org/10.1111/j.1365-2621.2011.02809.x

Chinma, C. E., Ramakrishnan, Y., Ilowefah, M., Hanis-Syazwani, M., \& Muhammad, K. (2015). REVIEW: Properties of Cereal Brans: A Review. Cereal Chemistry Journal, 92(1), 1-7. https://doi.org/10.1094/CCHEM-10-13-0221-RW

Coda, R., Katina, K., \& Rizzello, C. G. (2015). Bran bioprocessing for enhanced functional properties. Current Opinion in Food Science, 1, 50-55. https://doi.org/10.1016/j.cofs.2014.11.007

de Oliveira Leite, A. M., Miguel, M. A. L., Peixoto, R. S., Rosado, A. S., Silva, J. T., \& Paschoalin, V. M. F. (2013). Microbiological, technological and therapeutic properties of kefir: a natural probiotic beverage. Brazilian Journal of Microbiology: [Publication of the Brazilian Society for Microbiology], 44(2), 341-349. https://doi.org/10.1590/S151783822013000200001

Fang, S., Nadiah, W., \& Azizah, N. (2007). Physico-Chemical and Organoleptic Evaluation of Wheat Bread Subsituted with Different Percentage of Pumpkin Flour (Cucurbita moschata). ASEAN Food Journal, 14(2), 123-130.

Gautam, S.S. (2015). Assessment of Kefir and Sourdough on the Flavor Profile, Quality of White Bread and Rheology of Wheat Dough

Gobbetti, M., Rizzello, C. G., Di Cagno, R., \& De Angelis, M. (2014). How the sourdough may affect the functional features of leavened baked goods. Food Microbiology, 37, 30-40. https://doi.org/10.1016/j.fm.2013.04.012

Gül, H., Özçelik, S., Sağdıç, O., \& Certel, M. (2005). Sourdough bread production with lactobacilli and S. cerevisiae isolated from sourdoughs. Process Biochemistry, 40(2), 691-697. https://doi.org/10.1016/j.procbio.2004.01.044

Gurbuz, O., Gocmen, D., Ozmen, N., \& Dagdelen, F. (2010). EFFECTS OF YEAST, FERMENTATION TIME, AND PRESERVATION METHODS ON TARHANA. Preparative Biochemistry and Biotechnology, 40(4), 263-275. https://doi.org/10.1080/10826068.2010.488987

Hansen, se, \& Hansen, B. (1996). Flavour of sourdough wheat bread crumb. Zeitschrift $F$ Lebensmittel-Untersuchung Und -Forschung, 202(3), 244-249. https://doi.org/10.1007/BF01263548

Katina, K., Salmenkallio-Marttila, M., Partanen, R., Forssell, P., \& Autio, K. (2006). Effects of sourdough and enzymes on staling of high-fibre wheat bread. LWT - Food Science and Technology, 39(5), 479-491. https://doi.org/10.1016/j.Iwt.2005.03.013

Katina, Kati, Juvonen, R., Laitila, A., Flander, L., Nordlund, E., Kariluoto, S., Piironen, V., \& Poutanen, K. (2012). Fermented Wheat Bran as a Functional Ingredient in Baking. Cereal Chemistry Journal, 89(2), 126-134. https://doi.org/10.1094/CCHEM-08-11-0106

Luh, S. (1991). Rice Production and Utilization. The AVI Publishing Company, New York.

Östman, E. (2003). Fermentation as a Means of Optimizing the Glycaemic Index - Food Mechanisms and Metabolic Merits with Emphasis on Lactic Acid in Cereal Products. Lund Institute of Technology.

Poutanen, K., Flander, L., \& Katina, K. (2009). Sourdough and cereal fermentation in a nutritional perspective. Food Microbiology, 26(7), 693-699. 
https://doi.org/10.1016/j.fm.2009.07.011

Rösler, J., BäkerHarald, M., \& Harders, H. (2007). Mechanical Behaviour of Engineering Materials. Springer; 2007th edition.

Sayuti, I., Wulandari, S., \& Sari, K, D. (2013). Efektivitas Penambahan Ekstrak Ubi Jalar Ungu (Ipomoea batatas var. Ayamurasaki) Dan Susu Skim Terhadap Kadar Asam Laktat Dan $\mathrm{Ph}$ Yoghurt Jagung Manis (Zea Mays L. Saccharata) Dengan Menggunakan Inokulum Lactobacillus acidophilus Dan Bifidobacterium sp. Jurnal Biogenesis, 9(2), 21-27.

Shewry, P. R., Halford, N. G., Belton, P. S., \& Tatham, A. S. (2002). The structure and properties of gluten: an elastic protein from wheat grain. Philosophical Transactions of the Royal Society of London. Series B: Biological Sciences, 357(1418), 133-142. https://doi.org/10.1098/rstb.2001.1024

Simova, E., Beshkova, D., Angelov, A., Hristozova, T., Frengova, G., \& Spasov, Z. (2002). Lactic acid bacteria and yeasts in kefir grains and kefir made from them. Journal of Industrial Microbiology \& Biotechnology, 28(1), 1-6. https://doi.org/10.1038/sj/jim/7000186

Surono, I, S. (2004). Probiotik Susu Fermentasi dan Kesehatan. YAPMMI. Jakarta.

Torkamani, M. G., Razavi, S. H., \& Gharibzahedi, S. M. T. (2015). Critical quality attributes of Iranian 'Taftoon' breads as affected by the addition of rice bran sourdough with different lactobacilli. Quality Assurance and Safety of Crops \& Foods, 7(3), 305-311. https://doi.org/10.3920/QAS2013.0375

Wing, D., \& Scott, A. (1999). The Bread Builders Hearth Loaves and Masonry Ovens. White River Junction (VT): Chelsea Green Publishing Company. 